\title{
The Anti-oxidant and Anti-inflammatory Properties of Cerium Oxide Nanoparticles Synthesized Using Origanum majorana L. Leaf Extract
}

\author{
Ali Es-haghi*, Saynaz Aseyd Nezhad \\ Department of Biology, Mashhad Branch, Islamic Azad University, Mashhad, Iran
}

\author{
*Correspondence to \\ Ali Es-haghi \\ Email: ashaghi@gmail.com, \\ eshaghi5510@mshdiau.ac.ir
}

Received March 16, 2019 Accepted July 19, 2019 Published online September 30, 2019

\begin{abstract}
Introduction: Free radicals have singlet electron in their outer layer rendering them high reactivity against biomolecules (i.e., DNA, carbohydrates, proteins, and lipids). Oxidative stress is created when the production of free radicals exceeds their removal by antioxidant systems and is involved in the pathogenesis of several diseases such as diabetes, arthritis, inflammatory conditions, and various cancers. Regarding the therapeutic potential of nanoparticles (NPs) in human diseases, the purpose of this study was to synthesize cerium oxide NPs using Origanum majorana leaf extract. Methods: Cerium oxide nanoparticles $\left(\mathrm{CeO}_{2}-\mathrm{NPs}\right)$ were synthesized using aqueous leaf extract of O. majorana. The sizes of NPs were characterized by a particle size analyzer. The antioxidant properties of the $\mathrm{CeO}_{2}-\mathrm{NPs}$ were determined by Ferric-reducing antioxidant power (FRAP) assay. The anti-inflammatory effects of the NPs were also determined by measuring gene expressions of IL-1 $\beta$ and IL-10 using real-time polymerase chain reaction (PCR).

Results: The $\mathrm{CeO}_{2}-\mathrm{NPs}$ were successfully synthesized using $O$. majorana leaf extract. The results of FRAP assay showed that the anti-oxidant activities of $\mathrm{CeO}_{2}-\mathrm{NPs}$ at concentrations of 50, 100, and $400 \mu \mathrm{g} / \mathrm{mL}$ were $75 \%, 77.1 \%$, and $94.5 \%$, respectively. Moreover, interleukin 10 (IL-10) gene expressions increased by 4.6 folds while the expression of IL-1 $\beta$ gene decreased by 0.75 -fold in HUVECs.

Conclusion: The $\mathrm{CeO}_{2}-\mathrm{NPs}$ synthesized using the aqueous extract of $O$. majorana demonstrated antioxidant and anti-inflammatory properties. Therefore, these NPs can be used as potential therapeutic agents in medicine.

Keywords: Cerium oxide nanoparticle, Green synthesis, Origanum majorana, Interleukin, Antiinflammatory
\end{abstract}

Please cite this article as follows: Es-haghi A, Aseyd Nezhad S. The anti-oxidant and anti-inflammatory properties of cerium oxide nanoparticles synthesized using Origanum majorana L. leaf extract. Int J Basic Sci Med. 2019;4(3):108112. doi:10.15171/ ijbms.2019.20.

\section{Introduction}

Free radicals have one or more unpaired electrons in their outer electron layers. These molecules inflict the structure and function of various biological molecules such as nucleic acids, proteins, and lipids. ${ }^{1,2}$ Living organisms benefit from various antioxidant mechanisms to neutralize these free radicals. ${ }^{3}$ An imbalanced ratio of production and removal of free radicals triggers oxidative stress affecting cellular metabolism and multiple biological processes such as signal transduction, gene expression, cellular proliferation, and programmed cell death. ${ }^{4}$ Oxidative stress is involved in the pathogenesis of many disorders such as neurological diseases, diabetes, arthritis, inflammation, and cancer. $^{5}$

Inflammation is a complex host defense mechanism against invading microorganisms. Nevertheless, chronic inflammatory conditions can increase the risk of cancer and malignant transformation and modulate tumor angiogenesis and metastasis by suppressing anti-cancer immune responses. ${ }^{6}$

Nanoparticles (NPs) are materials with variable sizes (1-100 nm) and surface to volume ratios ${ }^{7}$, giving them unique physical, chemical, and biological properties. ${ }^{8-10}$ In previous studies, NPs have shown antioxidant, ${ }^{11}$ anti-bacterial, anti-inflammatory, ${ }^{12}$ anti-cancer and many other biological properties. ${ }^{13}$ Accordingly, NPs have considerably widespread

(C) 2019 The Author(s); Published by Zabol University of Medical Sciences. This is an open-access article distributed under the terms of the Creative Commons Attribution License (http://creativecommons.org/licenses/by/4.0), which permits unrestricted use, distribution, and reproduction in any medium, provided the original work is properly cited. 
applications in medicine, as well as pharmaceutical, food safety, and other industries. ${ }^{14}$ Cerium oxide $\left(\mathrm{CeO}_{2}\right)$ is a lanthanide metal oxide with anti-oxidative properties. ${ }^{15}$ $\mathrm{CeO}_{2}$ synthesized $\mathrm{NPs}\left(\mathrm{CeO}_{2}\right.$-NPs) have commonly been used in biomedicine as anti-cancer ${ }^{16}$ and wound healing agents. $^{17}$

Due to the presence of biologically active substances such as phenols, medicinal plants have been used for synthesizing NPs. ${ }^{18-20}$ Origanum majorana is a globally available medicinal plant grown in many regions of the world. In this study, the aqueous leaf extract of O. majorana was used to synthesize $\mathrm{CeO}_{2}$-NPs (i.e., green synthesis). The synthesized NPs were further characterized using the particle size analyzer. In addition, the anti-oxidant and anti-inflammatory properties of the $\mathrm{CeO}_{2}$-NPs were evaluated by Ferric-reducing antioxidant power (FRAP) assay and real-time PCR, respectively.

\section{Materials and Methods}

Chemicals and Reagents

The PCR Master Mix, SYBR green PCR master mix, RNeasy Mini Kit, and cDNA Synthesis Kit were purchased from Qiagen GmbH, Hilden (Germany). Other reagents not mentioned here were from Merck (Germany).

Preparation of Plant Extract and Synthesis of $\mathrm{CeO}_{2} \mathrm{NPs}$ In order to prepare the aqueous extract, $10 \mathrm{~g}$ of dried $O$. majorana leaf powder was added to $100 \mathrm{~mL}$ distilled water, heated up to $100^{\circ} \mathrm{C}$ and incubated for 10 minutes. For the biosynthesis of $\mathrm{CeO}_{2}$-NPs, $8.68 \mathrm{~g}$ of $\mathrm{Ce}\left(\mathrm{NO}_{3}\right)_{3} \cdot 6 \mathrm{H}_{2} \mathrm{O}$ was allowed to react with $200 \mathrm{~mL}$ of aqueous leaf extract of O. majorana. In the next step, the CeO-O. majorana mixture was dried at $100^{\circ} \mathrm{C}$ for 48 hours. Finally, the green-synthesized $\mathrm{CeO}_{2}$-NPs were purified by heating at $450^{\circ} \mathrm{C}$ for 4 hours to obtain brownish pellets.

Characterization Procedures

The synthetized $\mathrm{CeO}_{2}$-NPs were characterized using a particle size analyzer. ${ }^{21}$ In brief, the size distribution of NPs was analyzed using Zetasizer instrument (Malvern, UK). The diameter of $\mathrm{CeO}_{2}$-NPs was determined using NanoZS90 dynamic light scattering instrument (Malvern, UK) at a $90^{\circ}$ fixed-angle and room temperature.

\section{FRAP Assay}

The ferric reducing capacity of the $\mathrm{CeO}_{2}$-NPs was determined as described by Ozgen et al. ${ }^{22}$ One milliliter of different concentrations of CeO-O. majorana was mixed with $2.5 \mathrm{~mL}$ potassium phosphate buffer $(0.2 \mathrm{M}$, $\mathrm{pH}$ 6.6) and $2.5 \mathrm{~mL}$ potassium ferricyanide $(1 \mathrm{~g} / 100 \mathrm{~mL})$. The mixture was incubated at $50^{\circ} \mathrm{C}$ for 25 minutes. Then, trichloroacetic acid (10\%) was added to the mixture to stop the reaction. An equal volume of distilled water was subsequently added followed by addition of $0.5 \mathrm{~mL}$ ferum chlorate $(0.1 \mathrm{~g} / 100 \mathrm{~mL})\left(\mathrm{FeCl}_{3}\right)$. The procedure was carried out in triplicate. The mixture was allowed to stand for 30 minutes before measuring absorbance at $700 \mathrm{~nm}$.

Expression of Anti-inflammatory and Pro-inflammatory Genes

The expressions of interleukin 10 (IL-10) and IL- $1 \beta$ genes were determined in human umbilical vein endothelial cell (HUVEC) lines treated with the synthesized NPs. The cells were seeded at $5 \times 10^{3}$ cells $/ \mathrm{mL}$ concentration in a 6-well plate supplemented with RMPI 1640, FBS 10\%, and Pen-Strep $0.5 \%$. The cells were then treated with different concentrations of NPs (i.e., 0, 50, 100, and $200 \mu \mathrm{g} / \mathrm{mL}$ ) and incubated for 48 hours. At the end of incubation, the treated cells were washed with phosphate-buffered saline (PBS, 0.1 M, pH 7.2) twice and scraped with Trypsin. The gene expression of IL-10 and IL-1 $\beta$ was assessed using real-time PCR and primers mentioned in Table 1.

\section{RNA Extraction}

After 48 hours of incubation with the NPs, total RNA was extracted from the HUVECs. Briefly, $1 \mathrm{~mL}$ of the ice-cold RNX-plus solution was added to homogenized cells and mixed by vortexing. Then, $200 \mu \mathrm{L}$ chloroform was added and the solution was centrifuged at $12000 \times$ $\mathrm{g}$ for 15 minutes at $4^{\circ} \mathrm{C}$. An equal volume of isopropyl alcohol was added to the aqueous phase, and the mixture was centrifuged again. Afterwards, $75 \%$ ethanol $(1 \mathrm{~mL})$ was added to the supernatant. The solution was finally centrifuged to extract RNA. The RNA concentration was calculated using NanoDrop UV-Vis spectrophotometer followed by denaturing $1 \%$ agarose gel electrophoresis.

\section{cDNA Synthesis}

The cDNA was synthesized from the total extracted RNA using fermentase Kit according to the manufacturer's instructions. The mixture was incubated in thermal cycler for one cycle at $37^{\circ} \mathrm{C}$ for 15 minutes, one cycle at $85^{\circ} \mathrm{C}$ for 5 seconds and one cycle at $4^{\circ} \mathrm{C}$ for 5 minutes. In addition, samples without RT enzymes were used to detect contamination in the samples.

\section{Real-Time Polymerase Chain Reaction}

SYBR green-based real-time PCR (Qiagen Rotor-Gene Q, Hilden, Germany) was used to assess the expression of $I L$ $1 \beta$ and $I L-10$ genes. Amplification conditions were set as follows: an initial step at $95^{\circ} \mathrm{C}$ for 2 minutes followed by 30 cycles of $95^{\circ} \mathrm{C}$ for 15 seconds, $56.4^{\circ} \mathrm{C}$ for 20 seconds, and $72^{\circ} \mathrm{C}$ for 30 seconds. Melting curves were generated

Table 1. Primer Sequences for Analysis of IL-10 and IL-1 $\beta$ Gene Expression

\begin{tabular}{ll}
\hline Gene & Sequences $\left(\mathbf{5}^{\prime}\right.$ to $\mathbf{3}^{\prime}$ ) \\
\hline \multirow{2}{*}{ IL 10} & F TGGAGGACTTTAAGGGTTAC \\
& R GATGTCTGGGTCTTGGTT \\
IL 1 -B & F GCTTATTACAGTGGCAATGA \\
& R GTGGTCGGAGATTCGTAG \\
GAPDH & F CGTGCTGAATGAGGAACAGA \\
& R AGTCAGGGTGGACCTCAGTG \\
\hline
\end{tabular}


by monitoring the fluorescence of SYBR green signal from $65^{\circ} \mathrm{C}$ to $95^{\circ} \mathrm{C}$. GAPDH (glyceraldehyde 3-phosphate dehydrogenase) was used as the reference gene. Negative control contained ddH2O.

\section{Statistical Analysis}

The obtained data were analyzed by ANOVA test using SPSS software version 22.0. Significant results were confirmed by Duncan's multiple range test. $P$ value of less than 0.05 was considered statistically significant. All tests were performed in triplicate, and the results were expressed as mean values \pm standard deviations (mean \pm $\mathrm{SD})$.

\section{Results}

Nanoparticles Sizes

The results of particle size analysis are shown in Figure 1. The size of $\mathrm{CeO}_{2}-\mathrm{NPs}$ ranged from 10 to $70 \mathrm{~nm}$. The average particle size was about $25 \mathrm{~nm}$.

\section{Antioxidant Activity Assessments}

The antioxidant activity was investigated using FRAP assay by determining free radical scavenging capacity of the $\mathrm{CeO}_{2}$-NPs (Figure 2). The CeO-O. majorana mixture actively reduced $\mathrm{Fe}^{3+}$ to $\mathrm{Fe}^{2+}$. At concentrations of 50, 100, and $400 \mu \mathrm{g} / \mathrm{mL}$, the antioxidant capacities of $\mathrm{CeO}_{2}-\mathrm{NPs}$ were $75 \%, 77.1 \%$, and $94.5 \%$, respectively, indicating dose-dependent antioxidant activity of the synthesized $\mathrm{CeO}_{2}$-NPs.

Gene Expression of IL-10

The anti-inflammatory activity of $\mathrm{CeO}_{2}-\mathrm{NPs}$ was evaluated by measuring $I L-10$ gene expression as the main biomarker of anti-inflammatory immune response. HUVECs treated with $0,50,100$, and $200 \mu \mathrm{g} / \mathrm{mL} \mathrm{CeO}_{2}$ NP for 24 hours showed significant up-regulation of IL$10(P<0.001)$ as compared to untreated cells (Figure 3$)$.

\section{IL-1 $\beta$ Gene Expression}

The pro-inflammatory activity of $\mathrm{CeO}_{2}-\mathrm{NPs}$ was evaluated by assessing IL- $1 \beta$ gene expression as a pro-inflammatory biomarker. HUVECs treated with 50, 100, and $200 \mu \mathrm{g} / \mathrm{mL}$ $\mathrm{CeO}_{2}$-NPs for 24 hours were analyzed. Only at the 200 $\mu \mathrm{g} / \mathrm{mL}$ concentration, $\mathrm{CeO}_{2}-\mathrm{NPs}$ significantly decreased the expression of IL-1 $\beta$ gene compared with untreated control cells $(P<0.001$, Figure 4$)$.

\section{Discussion}

Several studies have reported potent antioxidant properties for $\mathrm{CeO}_{2}$-NPs. In this study, the green-synthesized $\mathrm{CeO}_{2}$ NPs (using O. majorana leaf extract) also revealed high antioxidant activity. At $400 \mu \mathrm{g} / \mathrm{mL}$ concentration, the synthesized $\mathrm{CeO}_{2}-\mathrm{NPs}$ reduced more than $94 \%$ of ferric $\left(\mathrm{Fe} 3^{+}\right.$) ions to ferrous $\left(\mathrm{Fe} 2^{+}\right)$. In another study, ROS content significantly decreased in $\mathrm{H} 9 \mathrm{C} 2$ cells exposed to $\mathrm{CeO}_{2}$-NPs with sizes of 1,10 , and $100 \mathrm{~nm}$ for 24 hours. ${ }^{23}$

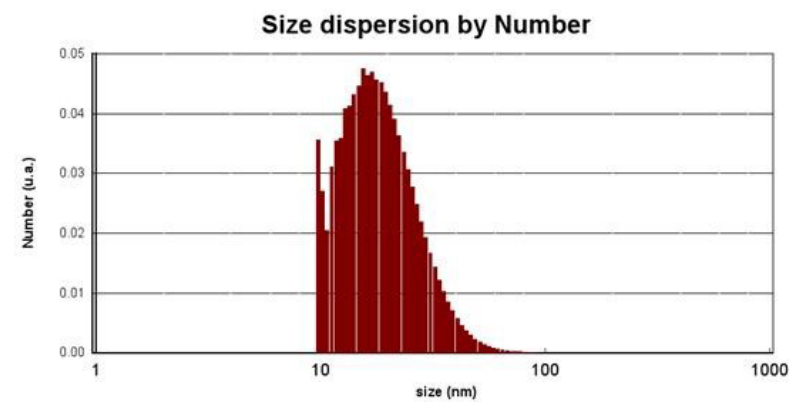

Figure 1. The Particle Size Distribution Analysis of CeO-NPs.

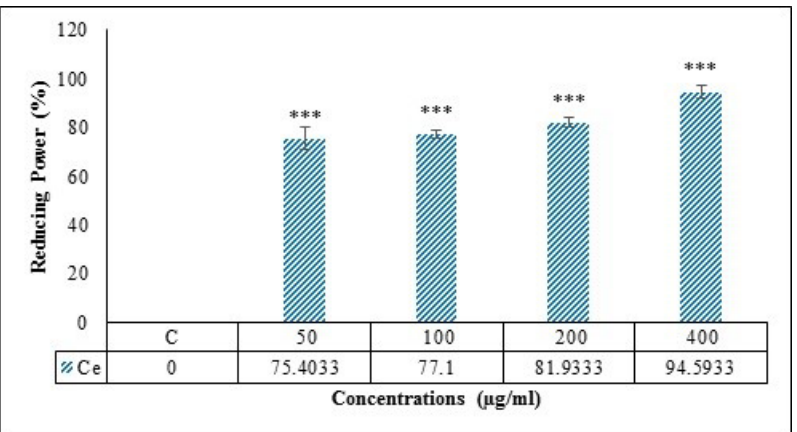

Figure 2. Ferric Reducing Antioxidant Activity of CeO-NPs Synthesized Using O. majorana L. Leaf Extract. The experiment was conducted in triplicate. ${ }^{* * *}$ $P<0.001$; significant difference as compared to the control (i.e., no $\mathrm{CeO}_{2}$ NP treatment).

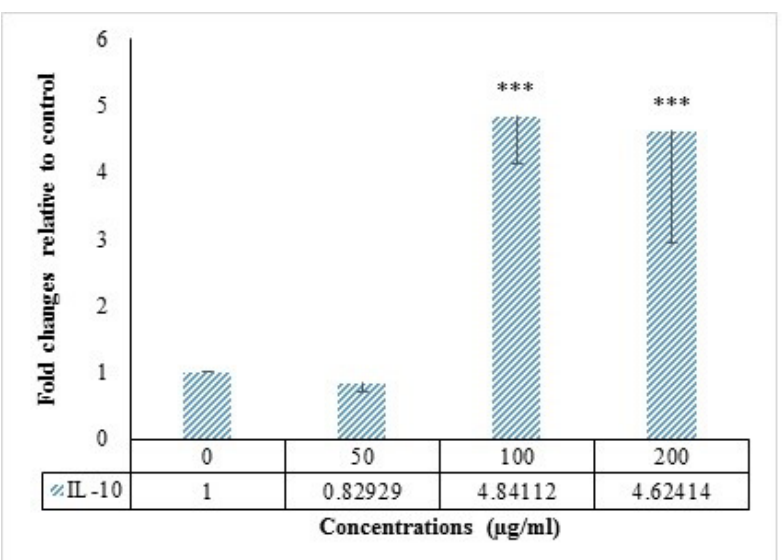

Figure 3. The Expression of $I L-10$ Gene in HUVECs Upon Treatment With 50,100 , and $200 \mu \mathrm{g} / \mathrm{mL}$ of $\mathrm{CeO}_{2}-\mathrm{NPs}$ for 24 Hours. ${ }^{* * *} P<0.001$ indicated significant difference compared with the control (i.e., no $\mathrm{CeO}_{2}-\mathrm{NP}$ treatment).

In another study, $\mathrm{CeO}_{2}$-NPs synthesized using the extract of Hyssopus officinalis plant effectively scavenged DPPH free radicals.

We here investigated the effects of $\mathrm{CeO}_{2}-\mathrm{NPs}$ on the gene expressions of IL-10 and IL-1 $\beta$ by real-time PCR. Accordingly, the expression of IL-10 (anti-inflammatory) significantly increased in a dose-dependent (50, 100, and $200 \mu \mathrm{g} / \mathrm{mL} \mathrm{CeO}_{2}$-NPs) manner. In addition, the expression of IL-1 $\beta$ (pro-inflammatory) significantly 


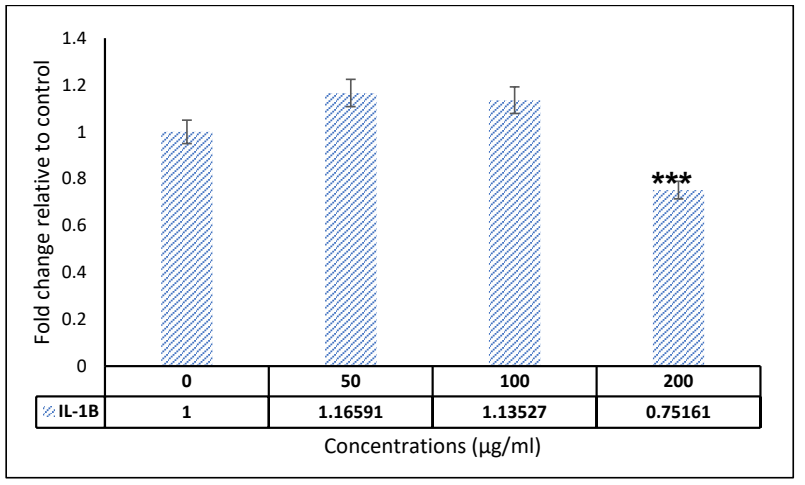

Figure 4. The Gene Expression of IL-1 $\beta$ in HUVECs Upon Treatment With 50,100 , and $200 \mu \mathrm{g} / \mathrm{mL} \mathrm{CeO}_{2}-\mathrm{NPs}$ for 24 Hours. ${ }^{*} P<0.05$, and ${ }^{* * *} P<0.001$ indicated significant differences compared with the control (i.e., no $\mathrm{CeO}_{2}$ NP treatment).

decreased at $200 \mu \mathrm{g} / \mathrm{mL}$ concentration of $\mathrm{CeO}_{2}-\mathrm{NPs}$.

Inflammation is a defensive mechanism protecting the body against various pathogens. Nevertheless, chronic inflammation can lead to various tissue damages and pathologic conditions..$^{24,25}$ Chronic inflammatory conditions may be triggered by genetic mutations, autoimmune diseases, or multiple environmental factors. ${ }^{26}$ In some cases, chronic inflammation may even lead to cancer. ${ }^{27}$

$\mathrm{CeO}_{2}$-NPs $\left(\mathrm{Ce}^{3+} / \mathrm{Ce}^{4+}\right)$ can have many therapeutic applications due to their potent antioxidative and antiinflammatory properties. ${ }^{28}$ Both anti-inflammatory and free-radical scavenging properties of $\mathrm{CeO}_{2}-\mathrm{NPs}$ have been shown in numerous studies. ${ }^{29-31}$ In another study, $\mathrm{CeO}_{2}-\mathrm{NPs}$ represented anti-inflammatory properties in the brain tissue of mouse accompanied by increased expression of iNOS gene. ${ }^{29}$ In BALF lymphocytes, anti-inflammatory properties of $\mathrm{CeO}_{2}$-NPs have been investigated by measuring pro-inflammatory genes expression (i.e., TNF- $\alpha$, IL-1 $\beta$, MIP-2, IL-13, and IFN- $\gamma$ ). ${ }^{32}$

The anti-inflammatory properties of $O$. majorana extract have also been investigated. In this study, we also assessed the anti-inflammatory effects of $O$. majorana extract in HUVECs. Our results showed that the expression of pro-inflammatory genes such as IL-1 $\beta$ decreased, while the expression of anti-inflammatory genes such as IL-10 increased in HUVECs. The antiinflammatory properties of O. majorana extract can be attributed to anti-inflammatory signaling pathways triggered by its ingredients. ${ }^{33}$

\section{Conclusion}

In this study, $\mathrm{CeO}_{2}$-NPs were synthesized using $\mathrm{O}$. majorana L. leaf extract and a bio-reduction method. The synthesized NPs exhibited all characteristic features of functional NPs. Our results confirmed the antioxidant and anti-inflammatory properties of the $\mathrm{CeO}_{2}-\mathrm{NPs}$. Our results suggested that these NPs can be used as antiinflammatory and anti-oxidative agents in biomedical fields. However, further in vivo studies are required.
Ethical Approval

Not applicable.

\section{Competing Interests}

The authors have no conflict of interest to declare.

\section{Acknowledgments}

The authors would like to thank the Department of Biology of Islamic Azad University of Mashhad Branch for the provided chemicals and laboratory facilities.

\section{References}

1. Lobo V, Patil A, Phatak A, Chandra N. Free radicals, antioxidants and functional foods: Impact on human health. Pharmacogn Rev. 2010;4(8):118-126. doi:10.4103/09737847.70902

2. Taghavizadeh Yazdi ME, Khara J, Housaindokht MR, et al. Biocomponents and antioxidant activity of Ribes khorasanicum. Int J Basic Sci Med. 2018;3(3):99-103. doi:10.15171/ijbsm.2018.18

3. Abdollahi M, Ranjbar A, Shadnia S, Nikfar S, Rezaie A. Pesticides and oxidative stress: a review. Med Sci Monit. 2004;10(6):Ra141-147.

4. Furukawa S, Fujita T, Shimabukuro M, et al. Increased oxidative stress in obesity and its impact on metabolic syndrome. J Clin Invest. 2004;114(12):1752-1761. doi:10.1172/jci21625

5. Valko M, Rhodes CJ, Moncol J, Izakovic M, Mazur M. Free radicals, metals and antioxidants in oxidative stressinduced cancer. Chem Biol Interact. 2006;160(1):1-40. doi:10.1016/j.cbi.2005.12.009

6. Hajhashemi V, Ghannadi A, Sharif B. Anti-inflammatory and analgesic effects of Coriandrum sativum $\mathrm{L}$. in animal models. Journal of Shahrekord University of Medical Sciences. 2003;5(2):8-15. [Persian].

7. Taghavizadeh Yazdi ME, Khara J, Sadeghnia HR, Esmaeilzadeh Bahabadi S, Darroudi M. Biosynthesis, characterization, and antibacterial activity of silver nanoparticles using Rheum turkestanicum shoots extract. Res Chem Intermediat. 2018;44(2):1325-1334. doi:10.1007/ s11164-017-3169-z

8. Hamidi A, Taghavizadeh Yazdi ME, Amiri MS, Hosseini HA, Darroudi M. Biological synthesis of silver nanoparticles in Tribulus terrestris L. extract and evaluation of their photocatalyst, antibacterial, and cytotoxicity effects. Res Chem Intermediat. 2019;45(5):2915-2925. doi:10.1007/ s11164-019-03770-y

9. Taghavizadeh Yazdi ME, Modarres M, Amiri MS, Darroudi M. Phyto-synthesis of silver nanoparticles using aerial extract of Salvia leriifolia Benth and evaluation of their antibacterial and photo-catalytic properties. Res Chem Intermediat. 2019;45(3):1105-1116. doi:10.1007/s11164018-3666-8

10. Taghavizadeh Yazdi ME, Khara J, Housaindokht MR, et al. Role of Ribes khorasanicum in the biosynthesis of silver nanoparticles and their antibacterial properties. IET Nanobiotechnol. 2019;13(2):189-192. doi:10.1049/ietnbt.2018.5215

11. Tsai YY, Oca-Cossio J, Agering $\mathrm{K}$, et al. Novel synthesis of cerium oxide nanoparticles for free 
radical scavenging. Nanomedicine. 2007;2(3):325-332. doi:10.2217/17435889.2.3.325

12. Jin K, Luo Z, Zhang B, Pang Z. Biomimetic nanoparticles for inflammation targeting. Acta Pharm Sin B. 2018;8(1):2333. doi:10.1016/j.apsb.2017.12.002

13. Taghavizadeh Yazdi ME, Amiri MS, Hosseini HA, et al. Plant-based synthesis of silver nanoparticles in Handelia trichophylla and their biological activities. Bull Mater Sci. 2019;42(4):155. doi:10.1007/s12034-019-1855-8

14. Bottini M, D’Annibale F, Magrini A, et al. Quantum dotdoped silica nanoparticles as probes for targeting of T-lymphocytes. Int J Nanomedicine. 2007;2(2):227-233.

15. Javadi F, Taghavizadeh Yazdi ME, Baghani M, EsHaghi A. Biosynthesis, characterization of cerium oxide nanoparticles using Ceratonia siliqua and evaluation of antioxidant and cytotoxicity activities. Mater Res Express. 2019;6(6):065408. doi:10.1088/2053-1591/ab08ff

16. Celardo I, Pedersen JZ, Traversa E, Ghibelli L. Pharmacological potential of cerium oxide nanoparticles. Nanoscale. 2011;3(4):1411-1420. doi:10.1039/c0nr00875c

17. Chigurupati S, Mughal MR, Okun E, et al. Effects of cerium oxide nanoparticles on the growth of keratinocytes, fibroblasts and vascular endothelial cells in cutaneous wound healing. Biomaterials. 2013;34(9):2194-2201. doi:10.1016/j.biomaterials.2012.11.061

18. Amiri MS, Joharchi MR, Taghavizadeh Yazdi ME. Ethnomedicinal plants used to cure jaundice by traditional healers of Mashhad, iran. Iran J Pharm Res. 2014;13(1):157-162.

19. Modarres M, Esmaeilzadeh Bahabadi S, Taghavizadeh Yazdi ME. Enhanced production of phenolic acids in cell suspension culture of Salvia leriifolia Benth. using growth regulators and sucrose. Cytotechnology. 2018;70(2):741750. doi:10.1007/s10616-017-0178-0

20. Dias AM, Hussain A, Marcos AS, Roque AC. A biotechnological perspective on the application of iron oxide magnetic colloids modified with polysaccharides. Biotechnol Adv. 2011;29(1):142-155. doi:10.1016/j. biotechadv.2010.10.003

21. Kumar B, Smita K, Cumbal L, Debut A. Green synthesis of silver nanoparticles using Andean blackberry fruit extract. Saudi J Biol Sci. 2017;24(1):45-50. doi:10.1016/j. sjbs.2015.09.006

22. Ozgen M, Reese RN, Tulio AZ Jr, Scheerens JC, Miller AR. Modified 2,2-azino-bis-3-ethylbenzothiazoline6-sulfonic acid (abts) method to measure antioxidant capacity of Selected small fruits and comparison to ferric reducing antioxidant power (FRAP) and 2,2'-diphenyl1-picrylhydrazyl (DPPH) methods. J Agric Food Chem.
2006;54(4):1151-1157. doi:10.1021/jf051960d

23. Rim KT, Kim SJ, Song SW, Park JS. Effect of cerium oxide nanoparticles to inflammation and oxidative DNA damages in H9c2 cells. Mol Cell Toxicol. 2012;8(3):271280. doi:10.1007/s13273-012-0033-5

24. Janeway CA, Travers P Jr, Walport M, Shlomchik MJ. Immunobiology: the immune system in health and disease. Vol 2. New York: Garland Pub; 2001.

25. Chen L, Deng $\mathrm{H}$, Cui $\mathrm{H}$, et al. Inflammatory responses and inflammation-associated diseases in organs. Oncotarget. 2018;9(6):7204-7218. doi:10.18632/oncotarget.23208

26. Jörg S, Grohme DA, Erzler M, et al. Environmental factors in autoimmune diseases and their role in multiple sclerosis. Cell Mol Life Sci. 2016;73(24):4611-4622. doi:10.1007/ s00018-016-2311-1

27. KhansariN,Shakiba Y,MahmoudiM.Chronicinflammation and oxidative stress as a major cause of age-related diseases and cancer. Recent Pat Inflamm Allergy Drug Discov. 2009;3(1):73-80. doi:10.2174/187221309787158371

28. Ivanov VK, Shcherbakov AB, Usatenko AV. Structure-sensitive properties and biomedical applications of nanodispersed cerium dioxide. Russ Chem Rev. 2009;78(9):855-871. doi:10.1070/ RC2009v078n09ABEH004058

29. Hirst SM, Karakoti AS, Tyler RD, Sriranganathan N, Seal S, Reilly CM. Anti-inflammatory properties of cerium oxide nanoparticles. Small. 2009;5(24):2848-2856. doi:10.1002/ smll.200901048

30. Niu J, Wang K, Kolattukudy PE. Cerium oxide nanoparticles inhibit oxidative stress and nuclear factor-kappaB activation in $\mathrm{H} 9 \mathrm{c} 2$ cardiomyocytes exposed to cigarette smoke extract. J Pharmacol Exp Ther. 2011;338(1):53-61. doi:10.1124/jpet.111.179978

31. Pagliari F, Mandoli C, Forte G, et al. Cerium oxide nanoparticles protect cardiac progenitor cells from oxidative stress. ACS Nano. 2012;6(5):3767-3775. doi:10.1021/nn2048069

32. Ocaña-Fuentes A, Arranz-Gutiérrez E, Señorans FJ, Reglero G. Supercritical fluid extraction of oregano (Origanum vulgare) essentials oils: anti-inflammatory properties based on cytokine response on THP-1 macrophages. Food Chem Toxicol. 2010;48(6):1568-1575. doi:10.1016/j. fct.2010.03.026

33. Cho WS, Duffin R, Poland CA, et al. Metal oxide nanoparticles induce unique inflammatory footprints in the lung: important implications for nanoparticle testing. Environ Health Perspect. 2010;118(12):1699-1706. doi:10.1289/ehp.1002201 